\title{
研究ノート
}

\section{圧力鍋調理後のビタミン残存量と煮汁中への アミノ酸溶出量}

\author{
尾 立 純 子, 藤 田 忠 雄*, 神 戸 保*, 大柴 恵 一* \\ 大阪市立環境科学研究所附設栄養専門学校, 大阪市立環境科学研究所食品栄養課* \\ Changes of Vitamins and Amino Acids in Foods after Pressure Cooking \\ Junko Odachi, Tadao Fujita*, Tamotsu Kanbe* and Keiichi Oshiba* \\ Osaka City Nutrition College, \\ *Department of Food Chemistry and Nutrition, Osaka City Institute of Public Health \\ and Environmental Sciences
}

The losses of vitamins and the liberations of amino acids in unpolished rice, soybeans and sweet potato after cooking with pressure pan ( $\mathrm{P}-\mathrm{pan})$ and original pan ( $\mathrm{O}-\mathrm{pan})$ were examined. The following results were obtained.

1) The loss of thiamin in unpolished rice after boiling with $\mathrm{P}$-pan was higher about $10 \%$ than that with O-pan. On the other hand, the loss of thiamin in soybeans after boiling with P-pan was lower about 15 to $20 \%$ than that with 0 -pan.

2) When the losses of thiamin and total ascorbic acid (AsA) in sweet potato ( $\alpha$-rate of starch: $90 \%$ ) after steaming with $\mathrm{P}$-pan was compared to that with $\mathrm{O}$-pan, the former cooking was higher about $10 \%$ in thiamin, $30 \%$ in AsA than the latter one.

3) Transfer of nitrogen and amino acids into boiling juice of soybeans after cooking with P-pan was higher about 1.5 times than that with $\mathrm{O}$-pan. The amino acids transfered more into boiling juice were tryptophan, arginine, alanine, glutamic acid and serine in descending order.

Jap. J. Nutr., 38 ( 5 ) 267 273 (1980)

\section{緒言}

近年, 省エネルギー問題が国民生活の中に大きくとりあげられているが，この間題を調理に扎いて考劣て見 ると, 数多く出回っている調理器具の中でも, 特に圧力鍋が然料を効果的に使う経済的な調理器具として着目 し得るであるう。

圧力鍋は蒸気の圧力で高湓 $\left(110 \sim 120^{\circ} \mathrm{C}\right)$, 高圧 $\left(1.2 \sim 1.5 \mathrm{~kg} / \mathrm{cm}^{2}\right)$ の状態で調理するために, 常圧鍋よ りも短い調理時間で済み, 然費も節減できる。また圧力鍋に適した調理方法も幅広く, 特に硬いものを軟かく するのに威力を発揮し，今後ますます利用範团も広まるものと考觉られる。

そこで, 著者らは圧力鍋と常圧鍋とで炊く, 煮る, 蒸す調理をそれぞれ玄米, 大豆, さつまいるを試料とし て, ビタミンの残存量ならびにアミノ酸の劣汁中への溶出量を比較検討したので, その結果を報告する。

\section{実 験 方 法}

1. 調理器具 
(1) 圧力鍋 : ピースプレッシャーパン, 大型 (PC-380 形, 直径 $20.5 \mathrm{~cm}$, 容量 $3.8 \mathrm{l}$ ), 小型 (PC-240形, 直径 $17.5 \mathrm{~cm}$, 容量 $2.4 \mathrm{l}$ )。

（2）常圧鍋：ホーロ一製（直径 $20.5 \mathrm{~cm}$, 容量 $3.8 \mathrm{l}$ ), アルマイト慜（直径 $24 \mathrm{~cm}$, 容量 $7 l$, 蒸し用)。

2. 調理方法

（1）玄米：玄米 $450 \mathrm{~g}$ を科取し，倍量の水で 4 回淘洗したのち，3 等分し，一定量の水に一晚つけた。圧力 鍋炊飯は沸騰後弱火で15分間炊き，火を止めて20分間むらした。常圧鍋炏飯は，沸騰後弱火で 2 時間炊き，火 を止めて20分間むらした。調理条件ならびに炊きあがり重量は表 1 に示すとおりである。

Table 1 Cooking conditions of unpolished rice

\begin{tabular}{lccc}
\hline \multirow{2}{*}{ Cooking method } & \multicolumn{2}{c}{ Cooking condition } & Weight after cooking \\
\cline { 2 - 3 } & $\begin{array}{c}\text { Unpolished rice } \\
(\mathrm{g})\end{array}$ & $\begin{array}{c}\text { Water } \\
(\mathrm{m} l)\end{array}$ & $(\mathrm{g})$ \\
\hline Original pan $^{1)}$ & 150 & 395 & $275 \sim 280$ \\
${\text { Pressure pan }(\text { large })^{2)}}_{\text {Pressure pan }(\text { small })^{1)}}^{150}$ & 150 & 195 & $275 \sim 280$ \\
& 195 & $290 \sim 300$ \\
\hline
\end{tabular}

1) Enameled pan is $20.5 \mathrm{~cm}$ in diameter and 3.81 in capacity.

2) Large and small of pressure pan are 20.5 and $17.5 \mathrm{~cm}$ in diameter, and 3.8 and 2.41 in capacity, respectively.

（2）大豆: 大豆 $450 \mathrm{~g}$ を科取し，倍量の水で洗った後， 3 等分し， $600 \mathrm{~m} l$ の水に一晚つけた。压力鍋では 沸騰後, 消火して30秒むらし, 冷水につけた。常圧鍋では沸騰後, 弱火で15分間募た。調理条件と煮あがりの 結果は表 2 亿示すと括りで每る。

Table 2 Cooking conditions of soybeans

\begin{tabular}{lcccccc}
\hline \multirow{2}{*}{ Cooking method } & \multicolumn{2}{c}{ Cooking condition } & & \multicolumn{2}{c}{ Weight after cooking } \\
\cline { 2 - 3 } \cline { 5 - 6 } & $\begin{array}{c}\text { Soybeans } \\
(\mathrm{g})\end{array}$ & $\begin{array}{c}\text { Water } \\
(\mathrm{m} l)\end{array}$ & & $\begin{array}{c}\text { Soybeans } \\
(\mathrm{g})\end{array}$ & $\begin{array}{c}\text { Boiling juice } \\
(\mathrm{g})\end{array}$ \\
\hline Original pan & 150 & 600 & & 367.2 & 111.2 \\
Pressure pan (large) & 150 & 600 & & 368.0 & 348.5 \\
Pressure pan (small) & 150 & 600 & & 361.6 & 365.1 \\
\hline
\end{tabular}

(3.)ささつまいも：さつまいも 1 個を縦に 4 等分または 6 等分し, 圧力鍋では沸騰後弱火で 5,10 及び15分間 蒸し，常压鍋では沸騰後強火で10，15，20，25及び30分間蒸した。

\section{3. 試料調製法}

生の玄米, 大豆は粉碎器を用いて粉末とし, 飯, 煮豆及びさつまいもは乳鉢を用いてょくすりつぶし均一化 した。大豆の煮汁はそのまま用いた。

\section{4. 測定方法}

水分は常圧加熱乾燥法1), 窒素はケールタ゚ール法1), ビタミン $\mathrm{B}_{1}$ (以下 $\mathrm{B}_{1}$ と略す) はチオクローム螢光 法 $^{2}$, ビタミン $\mathrm{B}_{2}$ (以下 $\mathrm{B}_{2}$ と略す) はルミフラビン螢光法 ${ }^{2}$, ビタミン $\mathrm{C}$ (以下 $\mathrm{C}$ と略す) はジニトロフェ ニルヒドラジン法2), でんぷん $\alpha$ 化度はジアスターゼ法3゙用いて測定した。アミノ酸は煮汁 $10 \mathrm{~m} l$ をとり， $1 \%$ ピクリン酸溶液 $20 \mathrm{~m} l$ を加克, 暫時放置後遠心分離した。その上澄液 $15 \mathrm{~m} l$ を陰イオン交換樹脂（アン 
バーライトCG-400)カラムを通し，ピクリン酸を除いたのち，0.02N-塩酸溶液でアミノ酸を完全に脱着した。 次に陽イオン樹脂（アンバーライト CG-120）カラムに通して, 糖質などを除いたのち，2N-アンモニア溶液 でアミノ酸を脱着させ, 脱着液を $40^{\circ} \mathrm{C}$ 減圧下で濃繀乾固し， $0.01 \mathrm{~N}$-塩酸溶液 $20 \mathrm{~m} l$ に溶解した。これをつ ミノ酸分析計（日本電子，JLC6AH 形）を用いて測定した。

\section{実 験 結 果}

1. 玄米及び大豆調理後のビタミ

\section{ン $\mathbf{B}_{1}$ 残存量}

圧力鍋及び常圧鍋調理に和ける玄 米ならびに大豆中の $\mathrm{B}_{1}$ 残存量を測 定し，その成績をそれ発れ図 $1 ， 2$ に示した。

玄米の炊飯後の $\mathrm{B}_{1}$ 残存量は，常 圧鍋で $72.4 \%(67.4 \sim 78.1 \%)$, 圧 力鍋大型で $64.1 \%$ (60.9 67.9\%), 小型で56.4\% (41.3〜 73.2\%）とな り, $\mathrm{B}_{1}$ 損失量は圧力鍋で常圧鍋に くらべて大きくなる傾向が認められ た。

また大豆調理後の $\mathrm{B}_{1}$ 残存量は, 常圧鍋で $51.3 \%$ （豆中 $50.0 \%$, 煮汁 中 $1.3 \%$ ), 圧力鍋大型で $69.6 \%$ (豆 中 $60.4 \%$, 煮汁中 $9.2 \%$ ), 小型で $64.7 \%$ (豆中 $56.7 \%$, 煮汁中 $8.0 \%$ ) であった。このように豆及び煮汁中 の $\mathrm{B}_{1}$ 残存量が圧力鍋で常圧鍋より も高くなり, 玄米調理の場合と逆の 結果が得られた。

\section{2. 玄米及び大豆調理後のビタミ}

\section{ン $\mathrm{B}_{2}$ 残存量}

圧力鍋と常圧鍋尤る調理後の玄 米及び大豆中の $\mathrm{B}_{2}$ 残存量を測定し, その成績のうち玄米についてのみ， 表 3 に示した。

玄米炊飯後の $\mathrm{B}_{2}$ 残存量は両鍋とも 100\%以上となり，炊 飯による損失 は認められなかった。また大豆につ

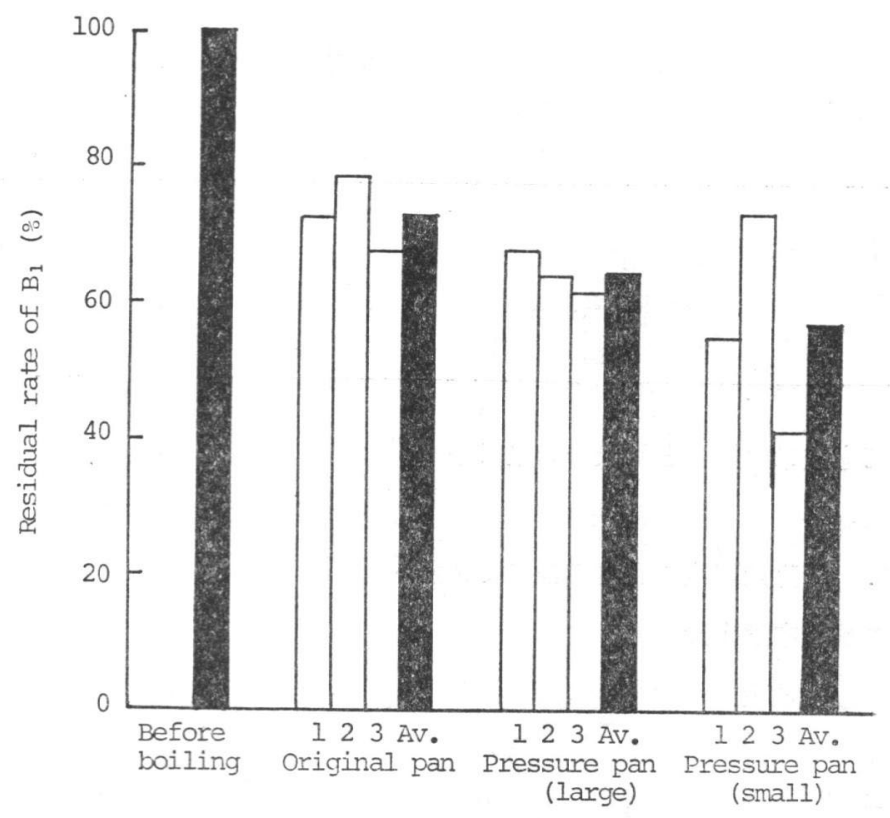

Fig. 1 Residual rate of vitamin $B_{1}$ in unpolished rice after cooking

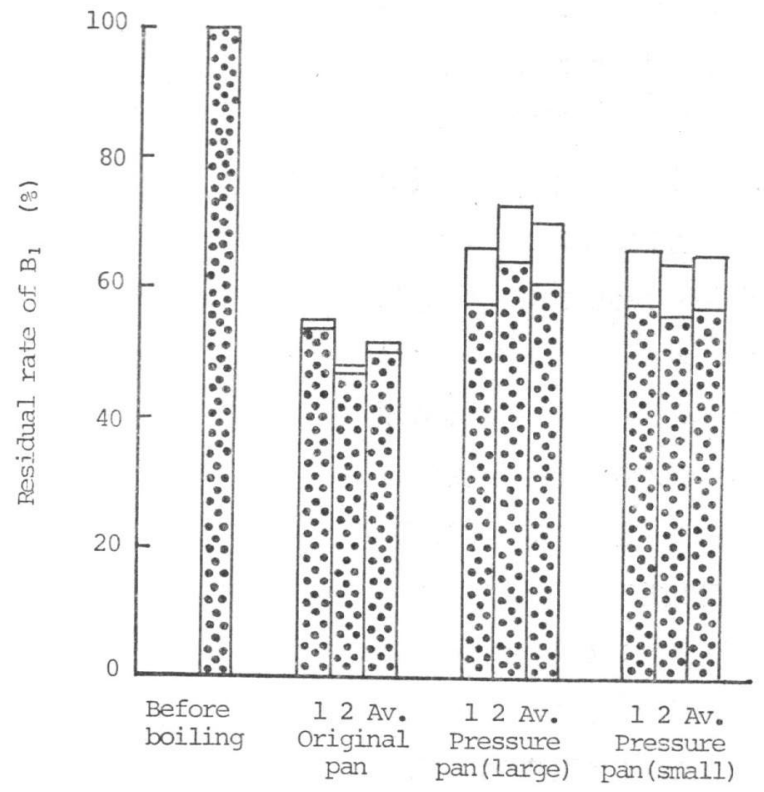

$B_{1}$ content in soybeans $\because \because$ in boiling juice

Fig. 2 Residual rate of vitamin $B_{1}$ in soybeans after cooking

(39) 
Table 3 Residual rate of vitamin $B_{2}$ in unpolished rice after cooking

\begin{tabular}{|c|c|c|c|c|c|c|}
\hline \multirow{2}{*}{$\begin{array}{l}\text { Sample } \\
\text { No. }\end{array}$} & \multirow[b]{2}{*}{ Cooking method } & \multirow{2}{*}{$\begin{array}{l}\text { Unpolished } \\
\text { rice }\end{array}$} & \multirow{2}{*}{$\begin{array}{c}\text { Water } \\
(\%)\end{array}$} & \multicolumn{2}{|c|}{ Vitamin $\mathrm{B}_{2}(\mathrm{mg} \%)$} & \multirow{2}{*}{$\begin{array}{c}\text { Residual } \\
\text { rate of } \\
\mathrm{B}_{2} \\
(\%)\end{array}$} \\
\hline & & & & $\begin{array}{l}\text { in wet } \\
\text { weight }\end{array}$ & $\begin{array}{l}\text { in dried } \\
\text { weight }\end{array}$ & \\
\hline \multirow{4}{*}{1} & & raw & 14.7 & 0.06 & 0.07 & 100 \\
\hline & Original pan & boiled & 57.1 & 0.03 & 0.07 & 100 \\
\hline & Pressure pan (large) & boiled & 55.1 & 0.03 & 0.07 & 100 \\
\hline & Pressure pan (small) & boiled & 55.2 & 0.04 & 0.09 & - \\
\hline \multirow{4}{*}{2} & & raw & 14.9 & 0.08 & 0.09 & 100 \\
\hline & Original pan & toiled & 65.1 & 0.03 & 0.09 & 100 \\
\hline & Pressure pan (large) & boiled & 57.0 & 0.05 & 0.12 & - \\
\hline & Pressure pan (small) & boiled & 56.8 & 0.05 & 0.12 & - \\
\hline
\end{tabular}

いても玄米の場合と同様の結果であ

$$
\text { った。 }
$$

3. 大豆調理後の窒素及びアミノ

\section{酸の煮汁中溶出量}

大豆調理後の煮汁中への窒素及び アミノ酸の溶出量を測定し, そのう

らアミノ酸についての成績を, 図 3 に示した。

大豆煮汁中への窒素の溶出量は, 常圧鍋で $3.81 \%$, 圧力鍋大型で5. 72 \%, 小型で6. $40 \%$ となり, 圧力鍋で は大きさによる差異は認められなか ったが，常圧鍋と比較して溶出量が 約 1.5 倍大きくなることがわかった。 一方煮汁中へ溶出しやすいアミノ酸 はトリプトファン，アルギニン，ア ラニン, グルタミン酸, セリンの順 であり, アミノ酸の種類別（中性, 酸性，塩基性，含硫了ミノ酸など） そよる一定の傾向は認められなかっ た。また溶出アミノ酸のパターンは 両鍋で差異がなかった。

4. さつまいも調理時のビタミン

\section{$\mathbf{B}_{2}$ 及びビタミン $\mathbf{C}$ 残存量}

さつまいるの調理時における $\mathrm{B}_{1}$ ならびにCの残存量を経時的に測定
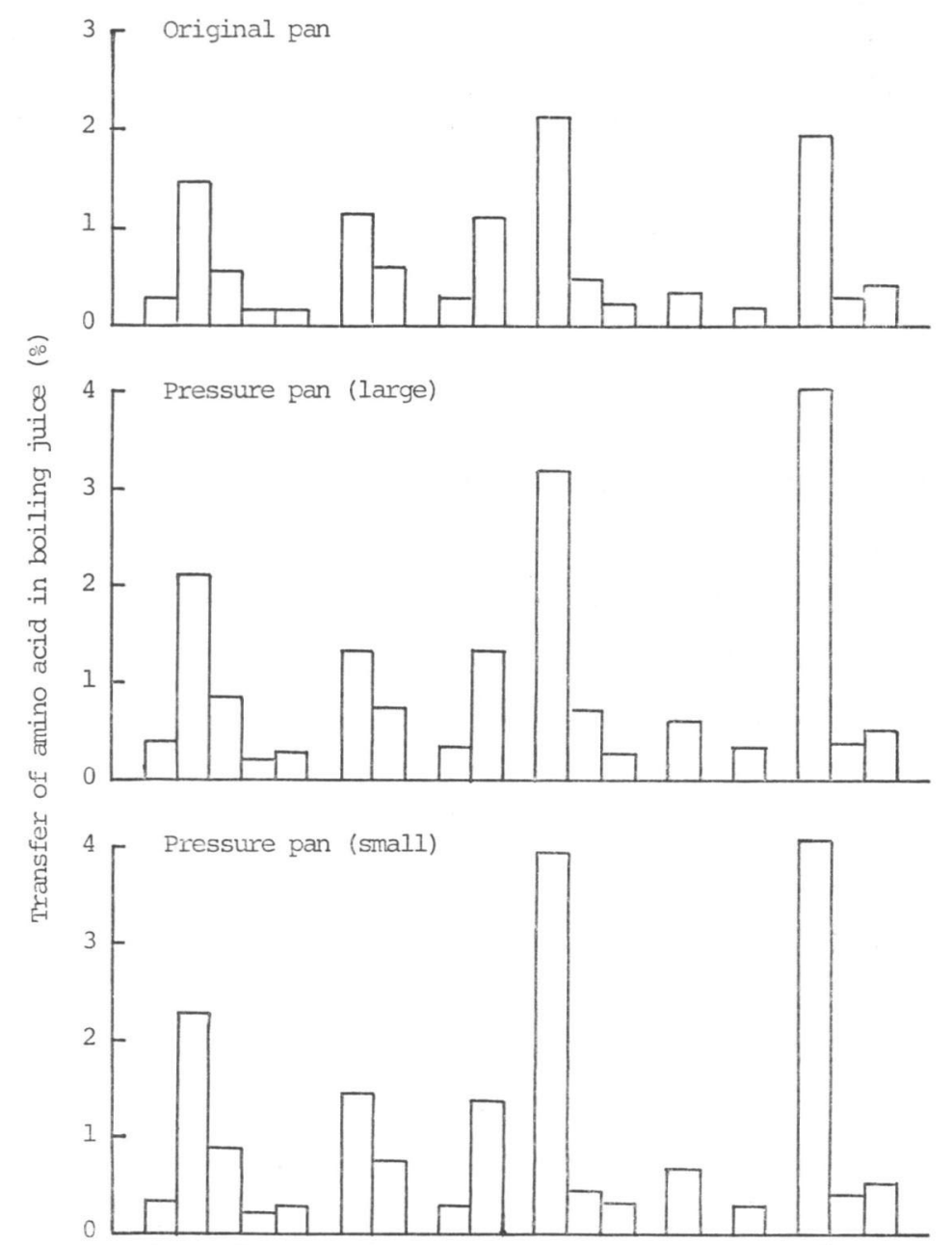

Gly. Val. Leu. Thr. Asp. Arg. Lys. Met. Pro. Phe. Ala. Ileu. Ser. Glu. His. Try. Tyr.

Fig. 3 Transfer of amino acids into boiling juice of soybeans after cooking.

(40) 
乙, 同時に蒸しあがりの指標と して, でんぷん $\alpha$ 化度を測定

し図 4 に示した。

常圧鍋調理の場合, でんぷん $\alpha$ 化度は10～20分の間で急激に 上昇し，25分で $95.7 \%$ となり， この時のビタミン残存量は $\mathrm{B}_{1}$ が84.5\%，Cが85.4\%と高かっ た。しかし，30分間調理では $\alpha$ 化度と $\mathrm{B}_{1}$ 量にはほとんと゚変動 が認められないが，Cの分解が 急速に進み, 残存量が70\%に落 ちた。一方, 圧力鍋の場合, $\alpha$ 化度は調理時間とともに直線的 飞上昇し，15分で $90.1 \%$ となり， これに逆比例して $\mathrm{B}_{1}$ の残存量 が減少し, 15分で73.1\%となっ た。またCの残存量は 5 〜 10 分 の間で急速に減少し, 15 分で

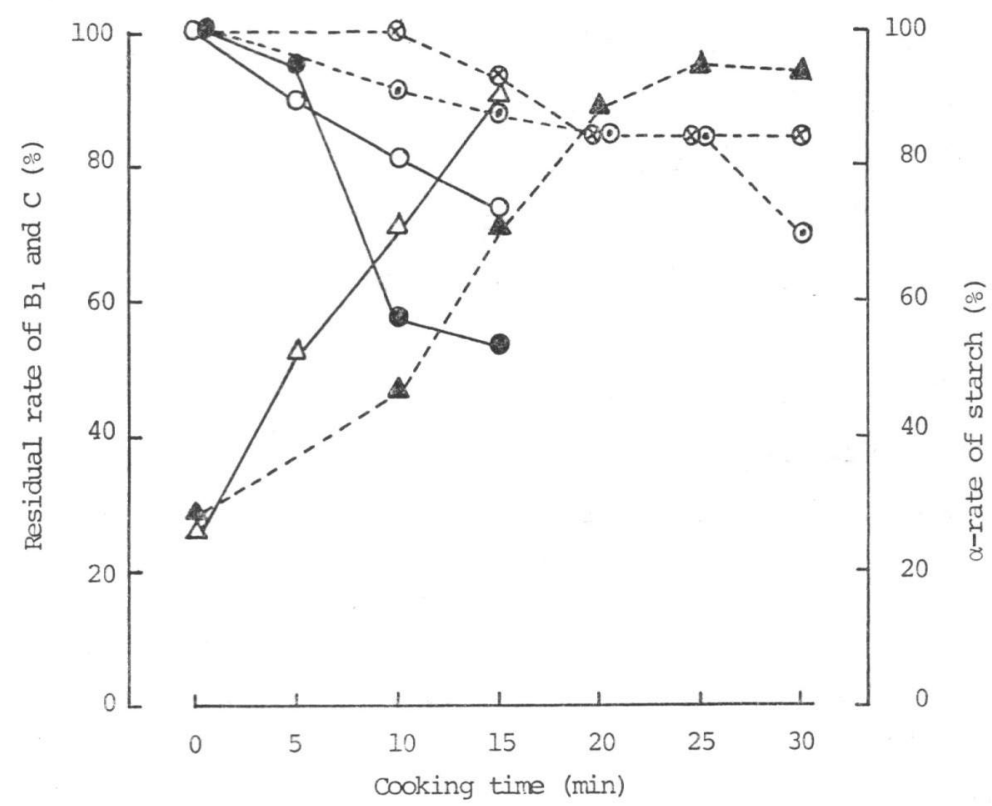

Fig. 4 Residual rate of vitamins and $\alpha$-rate of starch in sweet potato during cooking.

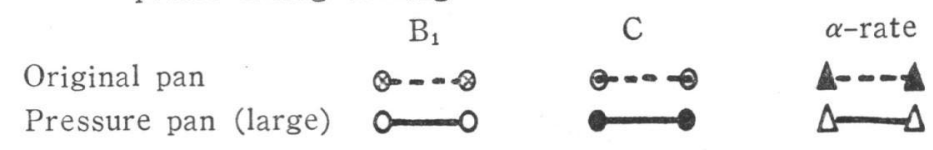

$53.8 \%$ となった。

\section{考察}

圧力鍋は食品を高温, 高圧で調理するために, 常圧調理に比較して栄養素の損失量に差異が生じるるのと考 えられた。

まず炊く調理として，玄米炊飯での $\mathrm{B}_{1}$ 量の変化を見た。圧力鍋調理後の $\mathrm{B}_{1}$ 損失量は，鍋の大きさによる 差異は明確には認められなかったが，常圧鍋よりも高くなる傾向が認められた。また圧力鍋小型では調理ごと に $\mathrm{B}_{1}$ 残存量が大きく変動することがわかった。本実験で $\mathrm{B}_{1}$ の損失量は, 汻洗 時と炊飯時の統量として測 定したが，玄米を同一条件で洗ったのちに分割し，炊飯に供したので，淘洗時の損失は各鍋で差がないるのと 考えてよいだろう。従って, 調理後の損失量の差異は, 炊飯時に生じた差と考学てもさしつかえないるのと考

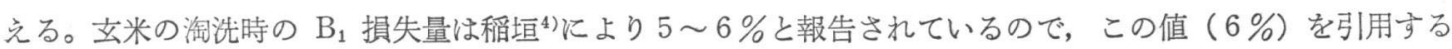
そ, 本実験での炊飯時のみの損失量は，常圧鍋で 15.9〜26.5\%, 圧力鍋大型で $26.1 \sim 33.1 \%$, 小型で 20.8 $52.7 \%$ 程度となる。このように玄米炊飯時の $\mathrm{B}_{1}$ 損失量は，圧力鍋では常圧鍋にくらべてわずかに高いようで ある。しかし，この程度の損失量の差異は玄米中の $\mathrm{B}_{1}$ 含有量から考えて，さほぼ問題にならないであろら。 一方，炊飯時間を比較すると，圧力鍋が約 15 分であるのに対して，常圧鍋では約 2 時間を要し，調理時間が短 縮され，乙かも燃費も可成り節約できるすのと思われる。

次に煮る調理として, 大豆を煮た場合の $\mathrm{B}_{1}$ 残存量, ならびに窒素及びアミノ酸の煮汁への溶出を比較し た。 $\mathrm{B}_{1}$ の残存量は豆及び煮汁中ともに压力鍋が高く，玄米炊飯の場合と逆の結果が得られた。圧力鍋調理の 
場合, 高圧の状態で調理を行らために, 調理温度が $110 〜 120^{\circ} \mathrm{C}$ と高くなり, 同時に食品にかなりの外圧がか かるために, 食品の組織細胞内へ調理飞用いた水が常圧の場合よりも入りやすくなり, 調理時間は短縮される が, 栄養素の溶出も短時間で大きくなるものと考兄られる。したがって食品中の栄養素は, 一旦調理水中に溶 出したのち, 分解が進むものと考光られる。一方, 大豆者汁中への窒素ならびにアミノ酸の溶出量は, 圧力鍋 の場合，常压鍋よりも約 1.5 倍多くなるが，各フミノ酸の溶出パターンは両鍋でまったく同じ傾向を示した。 また溶出されやすいアミノ酸は, アミノ酸の含有量, 分子構造及び性状などとは関係がないことから, おとら く, 大豆中の遊離型了ミノ酸の量と関倸があるものと考觉られる。

玄米及び大豆中の $\mathrm{B}_{2}$ 調理後の損失については， $\mathrm{B}_{2}$ 含量が低いために，その成績について比較することは適 当でないと考觉られる

さらに, 蒸し調理として, さつまいもの $\mathrm{B}_{1}$ とCの損失量を比較したが, 調理後の $\mathrm{B}_{1}$ とCの残存量が調理 ごとに大きく変動したために, 調理時のビタミンの残存量とでんぷん $\alpha$ 化度との関係を経時的に湘定し, 比 較した。 $\mathrm{B}_{1}$ については, 両鍋とも $\alpha$ 化度の上界に反比例して減少することが認められた。Cについても, $\alpha$ 化度の上年にともない減少したが, 圧力銆では $\alpha$ 化度 $50 \%$ 前後から急速に減少が起こるのにたいして, 常 圧鍋の場合には $\alpha$ 化度が90\%に達してから顕著な減少が起こるために， $\alpha$ 化度とCの損失量との間には相関 関係は認められなかった。したがって, さつまいもの蒸しあがる指標として, 官能的に最も優れていた $\alpha$ 化度 90\%前後をビタミン損失量の比較に用いるものが適当であると考光た。したがって, さつまいも調理後の $\mathrm{B}_{1}$ と C の残存量は, 圧力鍋で $\mathrm{B}_{1}$ が73\%, Cで $54 \%$, 常圧鍋で $\mathrm{B}_{1}, \mathrm{C}$ とに $85 \%$ となり, 圧力鍋での損失量が $\mathrm{B}_{1}$ で約10\%，Cで約30\%大きかった。

以上総合的にみて, 王力鍋調理時の栄養素の損失については, 調理後の調理水の残存の有無, 調理の時間及 び温度, 食品中の栄養素の存在形態なぞが, 大きく影響するるのと考兄られた。したがって, 圧力鍋は, 常圧 鍋と比較すると、これらを使った時, 栄盖学的にさほど遜色すなく, 官能的に優れたものができあがるという 事, しかも, 調理時間が非常に短縮されるために, 燃料消費節減にもなるだろうと思われる。このことから压 力鍋は豰類や種実類の調理器具としては, 非常に優れたものと考えてよいであうう。

要

約

圧力鍋と常圧鍋を用いて炊く，煮る，蒸す調理をそれぞれ玄米，大豆，さつまいもで行い，調理後のビタミ ン類の残存量とアミノ酸の煮汁中への溶出量を比較した。

1. 玄米を炊いた場合の $\mathrm{B}_{1}$ 残存量は，圧力鍋で 56 ～64\%常圧鍋で $72 \%$ となり，圧力鍋での損失量が約 $10 \%$ 大きかった。

2. 大豆を煮た場合の $\mathrm{B}_{1}$ 残存量は，力鍋で $65 〜 70 \%$ (豆中 $57 \sim 60 \%$, 煮汁中 8～9\%)，常圧鍋で $51 \%$ （豆中 $50 \% ，$ 煮汁中 1\%）となり，圧力鍋での損失量が約15〜20\%少なかった。

3. さつまいるを蒸した場合の $\mathrm{B}_{1}$ とC の残存量は, でんぶん $\alpha$ 化度約 $90 \%$ で比較すると, 圧力鍋で $\mathrm{B}_{1}$ $73 \% ， \mathrm{C} 54 \%$ ，常圧鍋で， $\mathrm{B}_{1} ， \mathrm{C}$ ともに $85 \%$ となり，圧力鍋での損失量が $\mathrm{B}_{1}$ で約 $10 \% ， \mathrm{C} て ゙$ 約 $30 \%$ 大きか った。

4. 大豆調理時の煮汁中への窒素とアミノ酸の溶出量は圧力鍋で常圧鍋の約1.5倍大きかった。また溶出さ れやすいアミノ酸はトリプトファン, アルギニン, アラニン, グルタミン酸, セリンの順で, アミノ酸の溶出 パターンは, 両鍋で差異はなかった。 
Vol. 38 No. 5

なお本研究の要旨は, 第26回日本栄養改善学会で発表した。

本実験を行らに際し, 御協力下さった大阪市立環境科学研究所附設栄養専門学校, 井上豊子, 太田千賀子, 大原良子, 長田美穂, 河村恵永の諸氏に感謝致します。

交献

1) 永原太郎, 岩尾裕之: 食品分析法, (1955) 柴田書店

2) 藤田秋治 : ビタミン定量法, (1955) 南江堂

3) 山下太郎 : 調理科学, 1, 24 (1968)

4) 稲垣長典：新編食品成分表, (1964) 大和文庫

(受付：昭和55年 8 月 20 日) 